\title{
2. Forms of Transnationalism, Forms of Tradition: Cloth and Cash as Ritual Exchange Valuables in the Tongan Diaspora
}

\author{
Ping-Ann Addo
}

\section{Introduction: Tongan Tradition and Transnational Economy}

Robin Cohen begins his list of the features of diaspora with following: 'dispersal from a traditional homeland ... [and] the expansion from a homeland in search of work, in pursuit of trade or to further colonial ambitions' (Cohen 2008,161). Labor for money is often cited as a main reason for emigration of Tongans overseas and to nodes in the Tongan diaspora. A decidedly transnational economy has resulted for members of this ethnoscape with Tongans traveling overseas from their homeland to earn and remit cash, thus enabling themselves and their families to purchase Western goods and other trappings of modernity. Because most remittances are sent directly to relatives in the homeland, I would add that the desire to fulfill abiding duties towards kin regardless of where they are located is an equally salient feature of modern diaspora. For people from the Kingdom of Tonga who have family ties connecting them to large diasporic communities like that dwelling in Auckland, New Zealand, the idea of laboring for money cannot be divorced from 'on-the-ground' efforts to maintain good social relations in communities in which social interactions are often public and usually highly scrutinized.

The transnational Tongan economy is intricately intertwined with the Tongan kingdom's economy through sending remittances, informal export of local goods which include ritual foods and textiles, and through the movement of people between communities in the Tongan ethnoscape (Lee 2004). Members of the Tongan diaspora remit cash and goods valued between 40 and 50 per cent of Tonga's GNP. These valuables are primarily categorised between family members as gifts (Brown 1998; Lee 2004). Indeed gifts that Tongans present to one another at ritual events such as funerals, weddings, and to other life crisis events generally constitute some combination of food, modern wealth (cash) and textiles (known as koloa and constituting traditional wealth). Sometimes, one kind of wealth is deemed more desirable than the other. Recent ethnography of Tongan exchange emphasizes the increased use of cash as gifts in ritual exchange (Addo 2004; Evans 2001; James 2002). This paper examines the case study of a funeral held by diasporic Tongans, members of a family who requested that condolence 
gifts brought to the event be only in the form of cash-textiles were not preferred. My analysis of the case reinforces Cohen's statement: the reality that Tongan families have made a practice of venturing from the homeland into diaspora in order to increase their access to cash. It also illuminates the extra-monetary expenditures which transnational Tongans (those who travel regularly or maintain active social and economic ties between homeland-based and diasporic communities) have to bear in order to perform rituals and otherwise 'be Tongan'. Moreover, it highlights how diasporic Tongans, as well as homeland Tongans interacting with each other negotiate modernity, the value of wealth and their social status.

Life crisis moments like funerals are times when the reputation of family is brought to the fore and it can be affected by how the family deals with gifts presented at the ritual. During my fieldwork in Tonga (2000-01), a family with whom I had grown very close tragically lost a daughter and her infant child in a car accident in Auckland, New Zealand, the city with the largest Tongan diasporic community. This was a difficult time, not least because of the death of a close relative, but also because travelling to host a funeral in New Zealand, a country where most of the deceased's immediate family did not live, would be costly in terms of time and money and could thus adversely affect the family's ability to maintain its reciprocal social relations. To circumvent the need to spend time reciprocating traditional wealth items like textiles, the family spread the word that they would be accepting no textile gifts, only cash gifts. The reason for their anomalous request was that they anticipated their time in Auckland would be limited, thus preventing them from reciprocating the textiles properly; cash would, and could, be reciprocated later, in accordance with modern customs. Their sentiments were made known via Tongan radio announcements and by word-of-mouth in both Tonga and in Auckland. One widely-held perception was that the family was trying to shirk tradition; another was that it was just inevitable that, with the increasing use of cash in gift exchange, in both Tonga and in the diaspora, money was finally beginning to show signs of replacing koloa faka-Tonga (women's valuables) in ritual presentations in diaspora. While this latter concern cannot be accurately answered-Tongan women's practice of koloa-making shows no trends toward either boom or bust (Addo 2007) - it is important to engage with analyses of traditional wealth with those of state currencies and their roles in contemporary Pacific societies. To this end, I address the question raised a decade ago by Melanesianists: why does cash seem to be replacing traditional gifts in the Tongan diaspora, but never eclipsing them (Akin and Robbins 1999, LiPuma 2000)? I ask: what can we learn from observing cultural practices in which exchange of traditional wealth incorporates money such that the gifting of cash throws intangible wealth, such as social relations, into relief? 


\section{Cloth and Cash}

In my experiences conducting fieldwork in Tongan communities in the Kingdom of Tonga and in Auckland, New Zealand, Tongans often discursively liken cash to cloth. For example, my informants frequently used the statement 'our koloa are like your money' when trying capture, for me - a Westerner - the value of their koloa. Such statements mask both the role koloa is made to play as a key symbol and the cultural knowledge that money is ranked below koloa as a ritual valuable. Money is a form of wealth, but koloa is 'what one treasures' (Herda 1999). Koloa constitute plaited mats, painted barkcloths, machine-made quilts and lengths of store-bought coloured fabric. Moreover, koloa are said to regenerate people culturally after the emotional and social rifts caused by life crisis moments and family disputes (Kaeppler 2000). Koloa also have long-standing meaning in Tongan society as bodily adornment, the spoils of war and the social possessions to which only highly ranked people had access (ibid.). They continue to constitute durable forms of wealth with which rule is legitimated and with which unions and unity of high-ranking lineages through weddings and births are cemented (Herda 1999; Kaeppler 1978a; Schneider and Weiner 1989). Koloa are quintessential gifts and marketable commodities: they can be exchanged as gifts at rituals, or sold or pawned for quick cash in both Tonga and abroad (see Addo and Besnier 2008). Koloa sent overseas constitutes important 'contraflows' to cash and other valuables sent from the diaspora to Tonga (James 1997).

Traditional wealth production and exchange embody gendered knowledge. Koloa connect key aspects of 'ulungānga faka-Tonga, knowledge of Tongan culture and traditions, which are among the things that Tongan women, especially, are charged with teaching children (Young Leslie 2004). In a brilliant discussion of the genealogical link to Pulotu, 'the world of the spirits' and the 'source of life and death', Filihia states: 'When women fabricate koloa, the mana of Pulotu is woven into their mats and hammered into their barkcloth, thus making these goods valuable items to be treasured' (Filihia 2001,387).

Men produce and gift objects called ngāue (Kaeppler 2000) or ngoue (Churchward 1959) that are the products of their farming activities. These include yams and other root crops, as well as livestock, especially pigs. In ceremonial exchange at life crisis events, koloa and ngäue/ngoue (today, often replaced by store bought luxury foods like tinned corned beef and bottled soft drinks) are reciprocated similarly with respective gifts of koloa or food. Probably because they are drawn from other families' valuable daily provisions, the practice is to reciprocate these gifts of food or of cloth in kind, and to do so soon after the ritual. Typically, whether in diaspora or homeland, koloa is reciprocated within days of a funeral. In ritual exchange, gifts of money are usually reciprocated in close to equivalent amounts, but during a later ritual at which the recipient in the former exchange is also involved. ${ }^{l}$ Money became associated, very early, with male activities 
since men were the first to engage in cash-related trade with Westerners (Addo and Besnier 2008). However, cash money is not a traditional wealth item for men; it remains a palangi (foreign) valuable.

Just as koloa itself belongs to two transactional orders (or types of economic exchange) - that of the gift and of the commodity - so too, money straddles the traditional economic sphere of the gift. To use Akin and Robbins' terms, money is regularly deployed in relationships defined by modes of sharing, as well as modes of equivalent exchange (Akin and Robbins 1999). ${ }^{2}$

\section{Money and Tradition}

Tongans use money today for daily modes of equivalent exchange, including financing staples (buying food and paying school fees, as well as purchasing clothes and household supplies). In modalities of sharing, or gift-exchange, cash is employed in ritual presentation at life crisis occasions (birthdays, christenings, weddings, funerals); for weekly and annual church donations; and as rewards for well-rendered artistic performances (dancing and singing at celebratory events or at fund-raising concerts). Cash gifts are always given in the local state currency of the country where the ritual is taking place, regardless of where the giver lives, works, or has travelled from. The money must therefore have the appropriate local form to be immediately useful. When a composite gift of cloth, cash and ngāue - or just of cloth and cash - is made, men and women are both implicated in the labour and love required to prepare the gift. Composite gifts indicate that members of a family - even those not present at the ritual - as invested in maintaining tradition as well as their family's reputation.

Among Tongans, having money is extremely important for being seen as able to uphold tradition. However, having money with no respect for tradition is considered antithetical to the most basic Tongan ideals of 'ofa (love) and faka'apa'apa (respect). An important aspect of tradition is making regular church donations and also gifts to clergymen. Adherents of the Free Wesleyan Church of Tonga, as well as other Tongan Methodist denominations in the ethnoscape, present annual donations known as misinale by gifting cash bills in a competitive and public forum (Decktor-Korn 1978). ${ }^{3}$ These cash gifts, amounting to a sum of between a few hundred and several thousand dollars, are a primary way in which large amounts of cash are remitted from diaspora to homeland (Lee 2004). There is a proper aesthetic to the formal gifting of money: it is enclosed in an envelope - usually white - called sila pa'anga, often resting atop a folded textile, and is presented with prayers and other gifts of food and drinks. When gifted during a dance, money is conspicuously tucked inside performers' necklines, waistbands, thrown into the air above their heads, or strung around their necks in a prepared garland. Wrapping or draping the body in things of beauty and of value predates the introduction of money to Tongan culture (Addo 2003), and to gift money in this way is to honour tradition. 


\section{Gifts and Funerals}

Tongan gift-givers and recipients are usually related as extended kin, or kāinga; branches of the kāinga normally constitute an immediate family (called a fāmili) related to the deceased through one member. In diaspora, funerals are a time to re-assemble far-flung kin, and people regularly travel between Tonga and diasporic communities to pay their last respects. A person's funeral is often the last time that $\mathrm{s} /$ he is physically surrounded a by a large number of kin and the last event at which s/he will be honoured by the exchange of gifts in her/his name and memory. Thus, funerals are as much moments for reunion and pride as they are moments for grieving. The esteem for the entire käinga rests on all constituent fämili groups to perform their appropriate ranked roles correctly (Kaeppler 1978b).

Gifts of food and cloth are long-standing material relations through which families help one another to sustain themselves in times of life crises. A gift of textiles, called a teu, is typically presented by a group of women, usually members of a fämili. As a representative of the gifting family makes an impassioned speech about the departed, the grieving family and the humble gifts the latter have brought, each piece of koloa is brought in and laid at the feet of a male representative of the receiving family, with cash in a sila pa'anga. Once presented, the cash and cloth gifts are removed to another room of the funeral venue, to be counted and noted along with the name of the givers. Friends, co-workers and kin members often bring gifts of food before the funeral; these are presented with prayers and sometimes with cash and cloth gifts. Traditionally, these gifts are considered necessary provisions for doing culture and, although they are wealth items, are also immediately useful.

Gifted food may be used to feed the mourners who come to pay their respects on the night of the wake or to sustain the bereaved family during its many days of preparation of and recuperation from the funeral; during this time, very little farming or fishing - and certainly no textile production - would be performed on estates and villages in Tonga. Because of the symbolism which koloa and feast foods maintain, to refuse a gift of cloth or food is seemingly to leave unrecognised another family's sacrifice and generosity and a refusal to do tradition. In addition, requesting money in lieu of koloa can be read as a preference for non-traditional ways over engaging in acts that honour both the dead and Tongan notions of tradition. Even when the grieving family in my case study explained that they still believed in Tongan traditions, their actions may have spoken (more loudly) of their attempting to eschew it. 


\section{Cash, Death and Diaspora: The Persistence of Gift-giving}

With high expectations of performing a funeral to honour society's expectations, this family's pride was also at stake. Nunia, the younger sister of the deceased woman, stated:

Dad stands to lose a lot of face from this funeral... but we have no choice. We can't afford to fly Malia ['s body] back [to Tonga] and have the funeral here. It would cost so much. We would even have to get people coming from New Zealand and Australia to bring some of the food if we were going to have it at home [in Tonga]. It's better to do it [in New Zealand]... and Mum and Dad decided last night not to take any teu... any koloa...because it would just be too hard for us to have to do the [reciprocal presentations] after the funeral. And we will be lucky if we get a month on our visas to stay [in New Zealand]. If we bury Malia in New Zealand...[my sister] Sona can look after her and visit her. We'll all visit her when we can. I know I will want to.

Nunia's father later told me that his fämili was willing to take risk 'losing face' in order to minimise the logistical challenges, and the monetary and cloth wealth costs of doing a traditional reciprocation, i.e., one involving the presentation of cloth, food and prayers, for each teu. Furthermore, the funeral was for both Malia and her young child, each of whom belonged to their respective fathers' lineages and therefore, ritually speaking, to a different fämili. Accepting only cash gifts would mitigate Nunia and Malia's family's obligations to immediately reciprocate numerous and costly gifts to two kin groups.

However, on the night of Malia and her baby's wake, Malia's fāmili was gifted with several traditional presentations of koloa. In the dim basement of an Auckland Methodist church, I listened and watched intently as the spokesperson for Nunia's family announced his thanks for one teu and subsequently relayed the grieving fämili's decision not to accept koloa on this occasion. On hearing this, one member from the gifting family picked up the envelope of money and handed it to the representative, then the women visitors picked up the koloa they had already laid down in front of him and left. I had also noticed one woman leaving the wake with her arms laden with koloa. Her koloa had obviously been refused. After hearing that the gift would not be accepted, she returned to her car, opened the trunk and practically dumped the koloa into it. Other visiting mourners would not be so easily deterred. Despite such obvious signs of distress about the refusal of koloa, another woman mourner found a way for the kāinga to accept her fämili's gift of koloa. I present an excerpt from my fieldnotes:

A relative of [Nunia's] mother's brother, a[nother] woman named Teuila who lived in Auckland and who, like the other visitors at the wake, had come in carrying part of a teu consisting of three pieces of [barkcloth], 
two decorated...mats, and several pieces of printed, store-bought fabric. After her fāmili had been thanked with a short, formal speech by [Nunia's] family representative and asked to remove their teu, she stood and took each of the ngatu with the mats folded up in them, and presented these to the three men from Malia's käinga who were seated in front of her, thereby making them the token gift recipients. The men all showed their acceptance of the gifts by saying ' $m \bar{a} l$ ' (thank you), and then Teuila and her [fāmili] group stood and left.

Two of Malia's sisters who had been seated nearby took Teuila's textiles into another room and they later analysed Teuila's motivations this way: 'She was being generous. It's like she just wanted someone to take the koloa from her, like if you offered me [some] chocolate and I didn't want to accept it, but you were going to give it away anyway, so you offer it to the person sitting next to me...' Another sister said: 'She was showing that she was liongi [in mourning] to the [family members] and the others with him. ${ }^{4}$ This second response revealed that the sister was well aware of the operation of roles at the funeral, rank being the principle governing who must gift and thus who receives and must reciprocate. Sensitivity to her own role and ritual ranked status permeated Teuila's sense of right and proper actions at this funeral and so she proceeded with her gift presentation. Similarly, Rupp reports on kokorozukai, a category of Japanese gifts generally given out of gratitude, for example to doctors for healing a sick family member or for delivering a healthy baby. According to Rupp: 'it is not possible to bring these gifts to the hospital, where there is a sign that reads: 'We humbly ask that you refrain from kokorozukai' [so] patients simply send their gifts directly to the doctors' residences' (Rupp 2003:163). In Rupp's example, presumably, the gifts are not refused.

In Tonga, just as in Japan, gifts already refused in one context may be accepted in another to save face for both givers and recipients. So, by ensuring that the gift moved on to another person at the ritual, Teuila fulfilled her duty in commemorating Malia's death. The counter-gift would have to be embodied in future gifts given by Nunia's famili members. The anthropology of Tonga is quite rich in analysis of Tongan gifts and countergifts (Addo 2004; Evans 2001; Gifford 1929; James 1997, 2002; Small 1997; van der Grijp 1993). These authors concur that, once accepted, an appropriate material gift must be reciprocated. To gift koloa is often termed 'mole [lose] koloa.' Even though the family did not reciprocate, they still engaged in exchange and were thus indebted to others. As Nunia said, they risked 'losing face'. They risked 'paying' for an easier funeral process with the esteem one would otherwise have in others' eyes following the ritual event. As a member of their käinga, extended family, Teuilia might have been trying to dispel any negativity associated with Nunia's famili's anomalous exchange practices. 
Friends and relatives also presented ngāue - food mostly in the form of store-bought frozen meat and root crops - to Nunia's fämili in Auckland on the night before the wake. Some of this food went towards a light meal prepared for visitors at the wake. In all, Nunia's fämili received NZ\$8,800 in condolence gifts from visitors to the Auckland funeral. This sum did not even begin to cover their initial outlay for their plane tickets from various parts of Tonga and Australia to Auckland, the expense of feeding the hundreds who attended, and the cost of countergifts (constituting cloth and store-bought food) to the six or seven Methodist ministers who visited during the night of the wake and the one who officiated at the burial. Still consumed by grief, Nunia's fämili returned to Tonga indebted monetarily, yet grateful for the great amount of spiritual and monetary support they received for dealing with their sudden double loss.

\section{Money as Tongan Gifts}

A gift of koloa remains a feature of diasporic ceremonial exchanges because its immediate reciprocation underscores the faith of those who also gave money. They believe that they can trust the receiving family to reciprocate cash in the future. As Kaeppler has suggested, koloa does indeed assure others of the continued sustenance and renewal of the kin group (Kaeppler 2000). Maintaining good social relations with käinga members who live in close proximity can be challenging, but trying to do so over the many miles between homeland and diaspora, or even between diasporic sites, can be daunting. If, like Nunia's family, the initial recipients of a gift are living far from Auckland when other families celebrate their next ritual, temporal and physical distance between rituals can make balanced and timely reciprocity of cash gifts almost impossible.

Thus, in diaspora, both gifts of money and cloth become fraught with much anxiety for both givers and recipients. The long-standing prescription of answering gifts with appropriate countergifts, even after costly and often sudden events such as funerals, is thrown out of sequence if only cash gifts are accepted. When people who give gifts receive no reward or material recognition for their material expenditure, the givers' feel disrespected and their family economics may also be adversely affected. In material terms, lay people - friends and other kin members who are not professionals like ministers and undertakers - receive no substantial public recognition for their material show of support. By accepting only cash Nunia's fāmili upset the sense of on-going, long-term, culturally-salient reciprocation, hence their fear of censure. A great deal more than koloa may be lost by refusing a gift that a diasporic dweller has taken pains to prepare and present to a homeland-based Tongan family; as Nunia said, 'a lot of face' is lost. A decision to reciprocate only some or even none of the gifts brought to a funeral is said, by some Tongans, to be the prerogative of oneself and one's family (Decktor-Korn 1978; James 2002; Kaeppler 1978b). Whether in diaspora or 
homeland, there seems to be little historical precedent for not succumbing to established pressures to gift cash, koloa and food at life crisis rituals.

Making gifts of cash in the context of times of ritual crises constitutes a symbolically important aspect of a generalized modality of sharing. It also assures continued prosperity for kin groups. ${ }^{5}$ Sharing money, helping a close relative to meet the costs of a child's education, or giving cash at a kinsperson's life crisis event is also a basic performance of tauhi vaha'a which Poltorak describes as a cultural value shared by Tongans and which emphasises the importance of caring for the 'space between' or the 'relatedness' of people (Poltorak 2007, 12). Explaining a dialectical variant of the same concept, Ka'ili describes the same phenomenon, which is also known as tauhi $v \bar{a}$, as operating transnationally and involving 'reciprocal exchange of economic and social goods' (Ka'ili 2005, 92). Sending money primarily from diasporic branches of the family to relatives in the homeland, is thus an important aspect of tauhi vaha'a/tauhi vā for it demonstrates willingness to support family materially. To upset this long-standing convention of Tongan exchange, whereby respect for kin and tradition is shown through the obvious and public bi-directional flow of gifts, is to challenge the very notion of Tongans constituting a common culture. It also engages Tongans in a dialogue about how Tonganness can be expressed given the challenges and possibilities presented by living in diaspora. As Matory cautions diaspora scholars to recognise: 'selective reproduction, meaning transformation, and meaningful reinterpretation of past cultural forms' involves 'commemoration [which] is always strategic in its selections, exclusions and interpretations' (Matory 2006: 163)

It remains to be seen how Tongan families will continue to finance and provide for each other through ritual exchange in the diaspora if the immediate reciprocations demanded by gifts of koloa are slowly made obsolete. Writing about Maori tangi, funerals, Sinclair states that such rituals are inevitable, yet regulating and familiar (Sinclair 1990). Funerals give life in an (immigrant Tongan) ethnic community in New Zealand a sense of spatial and temporal continuity because participants must perform roles, revisit the history of their social relations and consciously perform tauhi vā or tauhi vaha'a. No Tongan can control his or her rank, but the esteem within which a fämili, and consequently a käinga, is held can be positively or negatively affected through shared public assessments of an individual's attention to kinship matters like funerals (Kaeppler 1978b).

Tradition, in the form of kinship matters, will always concern families who are dispersed throughout the Tongan ethnoscape and for whom money makes staying connected-by phone, internet, courier mail and plane trips-increasingly manageable. However, as things that regenerate people culturally, cloth remains the symbolically potent material value with which many modern Tongans navigate the waters between upholding tradition and experimenting with 
modernity in the diaspora. As Tongan families continue koloa exchange, they construct these navigations as performances of anga faka-Tonga, even while money remains an important medium of Tongan daily and ceremonial exchange.

\section{Conclusion}

This paper has discussed the politics of money being made to stand in place of traditional wealth, textile koloa. Yet, the argument has also been presented that koloa continue to be indispensable to ritual and their role in connecting families. Koloa can only stand for themselves, and money is an inadequate stand in. As reflected on above, koloa are integral to the aesthetics of gifting cash. As explained earlier, sila pa'anga are often formally presented resting on a folded bed of koloa. Thus, money requires koloa in order to be gifted in ways that provide a further visual index for anga faka-Tonga. Perhaps this is one reason why gifts of cloth, as well as composite gifts of cloth and cash, have persisted almost 200 years into the existence of the monetised Tongan economy and with the increasing global spread of Tongan transnationalism.

For analytical neatness, I have presented a somewhat dichotomised view of cash and cloth wealth in the diasporic Tongan economy. In lived reality, however, cash and cloth are far more intertwined forms of wealth, bleeding into each other, but never fully eclipsing one another. Likewise, I have also separated the diaspora from the homeland as nodes of social experience, knowing full well that these practices are dialogic - mutually-constituting and carried out by social agents who negotiate the performance of traditions in their interactions and confrontations (Matory 2006). Tongan ceremonial culture in diaspora probably will continue to strongly affect ceremonial culture in the homeland. With this in mind, I have examined how a homeland-based fämili sought to make the politics of their own grieving process more bearable in material terms by vying for one form of value in a now thoroughly mixed economy of cash and cloth wealth.

Seen in an ethnographically nuanced light, we might re-think Cohen's second major feature of diaspora. Where Cohen cites 'expansion from a traditional homeland in search of work, in pursuit of trade' (Cohen 2008:161), I suggest we consider both permanent and temporary expansions from a homeland as well as the obvious intensification of relationships of emigrants with people still resident in that home land. Another feature of diaspora might also be the rights that emigrants maintain to negotiate a sense of tradition with their homeland-based counterparts. The (extra-local) search for work and the transnational performance of tradition have become basic features of Tongan modernity as well as basic assumptions about how diaspora contributes to the longevity of Tongan culture writ large. 
In concluding, I make no predictions about how Tongan diaspora and notions of modernity will affect the intertwined roles of cash and cloth in Tongan exchange. For example, no one can accurately predict if cash gifts will indeed replace cloth gifts in the future. While the relationship of these two categories of valuables has been historically established in Tongan culture, my discussion here has shown that the relationship is subject to much negotiation, especially as life crisis rituals, and decisions around them, may be bi-territorially planned and executed. To see cash and cloth as equivalent forms of value such that one form (money) might replace the other (koloa) in ritual exchange, would be to ignore just what is at stake in contemporary transnational identities: good social relations.

This chapter is dedicated to the loving memory of the late Henry Kilifi Quensell and his entire fāmili. Na'a ne haka he langi, Māl .

\section{References}

Addo, P-A. 2003. God's kingdom in Auckland: Tongan Christian dress and the expression of duty. In Clothing the Pacific, ed. Chloe Colchester, 141-63. Oxford: Berg Press.

—. 2004. Kinship, cloth, and community in Auckland, New Zealand: Commoner Tongan women navigate transnational identity using traditionally-styled textile wealth. PhD thesis, Yale University.

—. 2007. Tongan women authenticate ngatu pepa in New Zealand. Pacific Studies, New Series 3:60-73.

Addo, P-A. and N. Besnier. 2008. When gifts become commodities: Pawnshops in Tonga and the Tongan diaspora. Journal of the Royal Anthropological Institute 14 (19): 39-59.

Akins, D. and J. Robbins. 1999. State and local currencies in Melanesia. Pittsburgh: University of Pittsburgh Press.

Brown, R. 1998. Do migrants' remittances decline over time: Evidence from Tongans and Western Samoans in Australia. The Contemporary Pacific 10 (1): 107-52.

Churchward, C. 1959. Tongan dictionary. London: Oxford University Press.

Cohen, R. 2008. Global diasporas: An introduction. New York: Routledge.

Decktor Korn. S. 1978. After the missionaries came: Denominational diversity in the Tonga Islands. In Missions, church, and sect in Oceania, ed. J. A. Boutilier, D. T. Hughes, and S. W. Tiffany, 395-422. Ann Arbor, MI: University of Michigan Press.

Evans, M. 2001. Persistence of the gift: Tongan tradition in transnational context. Waterloo, Ontario: Wilfred Laurier University Press. 
Filihia, M. 2001. Men are from Maama, women are from Pulotu: Female status in Tongan society. Journal of the Polynesian Society 110 (4): 377-90.

Gifford, E. W. 1929. Tongan society. Bernice P. Bishop Museum Bulletin, no. 16. Honolulu: Bishop Museum.

Herda, P. 1999. The changing texture of textiles in Tonga. Journal of the Polynesian Society 108 (2): 149-67.

James, K. 1997. Reading the leaves: The role of Tongan women's traditional wealth and other 'contraflows' in the processes of modern migration and remittance. Pacific Studies 20 (1): 1-27.

- 2002. The cost of custom: A recent funeral in Tonga. Journal of the Polynesian Society 111 (3): 223-38.

Kaeppler, A. 1978a. Exchange patterns in goods and spouses: Fiji, Tonga, and Samoa. Mankind 11 (3): 246-252.

- 1978b. Me'a faka'eiki: Tongan funerals in a changing society. In The changing Pacific: Essays in honour of Henry Maude, ed. Neil Gunson, 174-202. Melbourne: Oxford University Press.

- 2000 . From the stone age to the space age in 200 years: Tongan art and society at the eve of the millennium. Tofoa, Kingdom of Tonga: Tonga National Museum.

Ka'ili, T. 2005. Tauhi vā: Nurturing Tongan sociospatial ties in Maui and beyond. The Contemporary Pacific 17 (1): 83-114.

Lee, H. 2004. 'Second generation' Tongan transnationalism: Hope for the future? Asia Pacific Viewpoint 45 (2): 235-54.

LiPuma, E. 2000. Encompassing others: The magic of modernity in Melanesia. Ann Arbor: University of Michigan Press.

Matory, J. 2006. The New World surrounds an ocean: Theorizing the live dialogue between African and African American cultures. In Afro-Atlantic dialogues: Anthropology in the diaspora, ed. K.A. Yelvington, 151-192. Santa Fe: School for American Research Press.

Poltorak, M. 2007. Nemesis, speaking, and tauhi vaha'a: Interdisciplinarity and the truth of mental illness in Vava'u, Tonga. The Contemporary Pacific 19 (10): 1-38.

Rupp, K. 2003. Gift-giving in Japan: Cash, connections, cosmologies. Stanford: Stanford University Press.

Rutherford, N. 1977. George Tupou I and Shirley Baker. In Friendly islands: A history of Tonga, ed. Noel Rutherford, 154-72. Melbourne: Oxford University Press. 
Schneider, J. and A. Weiner. 1989. Cloth and human experience. Washington: Smithsonian Institution Press.

Sinclair, K. 1990. Tangi: Funeral rituals and the construction of Maori identity. In Cultural identity and ethnicity in the South Pacific, ed. J. Linnekin and L. Poyer, 218-36. Honolulu: University of Hawai'i Press.

Small, C. 1997. Voyages: From Tongan villages to American suburbs. Ithaca, NY: Cornell University Press.

Van der Grijp, P. 1993. Islanders of the south: Production, kinship, and ideology in the Polynesian kingdom of Tonga. Leiden: KITLV Press.

Young Leslie, H. 2004. Pushing children up: Maternal obligation, modernity, and medicine in the Tongan ethnoscape. In Globalization and culture change in the Pacific Islands, ed. V. Lockwood, 390-413. Upper Saddle River, New Jersey: Prentice Hall.

\section{ENDNOTES}

${ }^{1}$ Just as Rupp explains for Japanese gifts of money I suggest that, among Tongans, returning equivalent amounts immediately might be considered 'too calculating' (Rupp 2003).

2 Akin and Robbins (1999) use this term to indicate that the significance of money shifts depending on whether it is deployed in a modality of equivalence (most commonly as a commodity) or sharing (as a gift), which contextualise the relevant social relations.

3 Money entered the world of Tongan exchange alongside Christianity and was eventually localised through gifting money in the manner of traditional valuables. Fakamisinale (making missionary) was a financial mainstay of the local church, with donations at first being accepted in the form of commodities such as copra and coconut oil. Peruvian and Chilean coin-again, introduced through the copra trade - were the first state currencies Tongans used, after the Australian-based London Missionary Society (LMS) church administration decreed that Tongans should pay their annual church donations in modern cash (Rutherford 1977). The silver coins were shiny and showy, just the thing for distinguishing one's family and honoring a generous God, from whom all other blessings flowed.

4 Liongi is a state of ritual mourning usually physically characterised by the wearing of large and tattered waist mats over black clothes.

5 The form and timeliness of a countergift delivers a message about one's regard for social rules and kin-based roles (James 2002). In the 1920s Gifford recorded the lengths to which Tongan families would go to ensure that they reciprocated gifts appropriately. Citing an example of wedding gifts exchanged between bride and groom's sides in Nuku'alofa, Tonga, he says: 'In accomplishing [a] return the distributor often stripped his own house of all its possessions, counting the social prestige of his family of greater value than his material property. If he should fail to complete the traditional remuneration to all concerned, his unmarried sons and daughters and the progeny of his married children lost face and might consequently fail to contract desirable marriages' (Gifford, 1929, 193). 